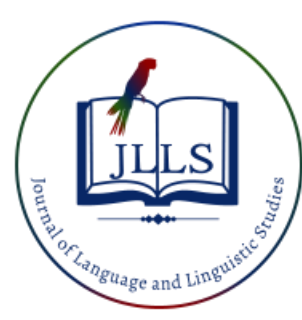

Available online at www.jlls.org

JOURNAL OF LANGUAGE AND LINGUISTIC STUDIES

ISSN: $1305-578 \mathrm{X}$

Journal of Language and Linguistic Studies, 16(3), 1264-1281; 2020

\title{
Pragmatic transfer in Turkish EFL learners' compliments and compliment responses from L1 Turkish to L2 English
}

\author{
Tuba Karagöz Dilek ${ }^{\text {a1 }}$ \\ ${ }^{a}$ Gazi University, Ankara, Turkey
}

\section{APA Citation:}

Karagöz-Dilek, T. (2020). Pragmatic transfer in Turkish EFL learner's compliments and responses from L1 Turkish to L2 English. Journal of Language and Linguistic Studies, 16(3), 1264-1281.

Submission Date:06/04/2020

Acceptance Date:30/06/2020

\begin{abstract}
The present study aimed to figure out whether Turkish EFL learners transfer their L1 Turkish pragmatic norms to their L2 English compliments and compliment responses. Six senior ELT students took part in the study, carried out at a state university in Turkey. An open role play adapted from Tran's study (2006) was used in English and Turkish to elicit the compliment and compliment response data in the given languages. The data analysis was carried out according to two different coding schemas. The compliment strategy framework, used to analyze compliment strategies, consisted of two macro levels as direct compliments and indirect compliments and subcategories. The second framework that was used to analyze responses to compliments yielded three main categories as Accept compliments, Reject compliments, Deflect/ Evade compliments and their sub-categories. The results of the study implied that there was a sign of negative pragmatic transfer from L1 Turkish to L2 English in Accompanied by Explanations compliment strategy at the level of direct compliments and the results also suggested that Turkish EFL learners transferred the use of Deflect/Evade compliment response strategy especially in the sub-category of Explanation from their L1 to their L2 English.
\end{abstract}

(C) 2020 JLLS and the Authors - Published by JLLS.

Keywords: speech act; compliment strategy; compliment responses; pragmatic transfer

\section{Introduction}

Speech acts, which refer to functions or actions of utterances in language (Austin, 1962), have attracted a considerable amount of attention among researchers and have constituted the core of the research carried out within the field of interlanguage pragmatics. Interlanguage pragmatics is concerned with how non-native speakers use and acquire second language (L2) pragmatic knowledge (Kasper, 1992). This is very crucial because L2 learning is a complex process and there are a lot of aspects of a language that second language learners (L2) need to learn. One of them is apparently pragmatic knowledge, which is a challenging area for L2 learners as they are mostly not aware of this aspect of language. L2 learners also may not be conscious of the possible negative effects of pragmatic failure

\footnotetext{
${ }^{1}$ Corresponding author. Tel:

E-mail addres: tubakaragoz@gazi.edu.tr
} 
like misunderstandings that could occur due to the lack of this knowledge (Gass, 2013). Each language and culture have their own pragmatic norms. L2 learners in English as a foreign language (EFL) context are not exposed to L2 input in their daily life, which makes it harder for them to use speech acts like compliment and compliment response strategies appropriately in their L2. Therefore, they need to pay extra attention to the target pragmatic norms of the target culture and language accordingly when learning L2, otherwise communication breakdowns might occur between the speakers. L2 learners might face "pragmatic failure" owing to the pragmatic transfer issue as L2 learners show a tendency to transfer the pragmatic aspects of their native language to their L2 (Kasper, 1992; Thomas, 1983). Pragmatic transfer is a term to define this phenomenon. That is to say, it can be described as "the influence exerted learners' pragmatic knowledge of languages and cultures other than L2 on their comprehension, production and learning of L2 pragmatic information" (Kasper, 1992, p. 207). Positive transfer occurs where L1 and L2 have parallel features, and negative transfer may occur where L1 and L2 have contrasting properties. The negative transfer is more critical for the present study because of its inhibitive effects in adopting the target pragmatic norms.

Speech acts can be performed quite differently across different cultures. Using more interrogative and conditional forms in English compared with Polish can be just a tiny example of how the use of speech acts differs from language to language (Wierzbicka, 1985). These differences could lead to a considerable amount of difficulty for L2 learners (Han, 1992). For instance, a recent study carried out by Karagöz and İşisağ (2019) suggests that Turkish EFL students seem to have problems with requesting of a higher-status person appropriately in terms of the level of indirectness in English. Such situations may cause misunderstandings for EFL learners during their communication in L2.

Compliments are studied within this respect for this study. Holmes (1988, p. 446) defines a compliment as, "a speech act which explicitly or implicitly attributes credit to someone other than the speaker, usually the person addressed, for some 'good' (possession, characteristic, skill etc.) which is positively valued by the speaker and the hearer". Compliments produced in a particular language seem to reflect sociocultural values of that culture and learning to compliment and respond to compliments in accordance with the target culture can provide L2 learners with chances to be in more meaningful social interaction with native speakers (Billmyer, 1990).

Few studies (e.g. Varol, 2015) have so far studied pragmatic transfer in complimenting or responding to complimenting for L1 Turkish L2 English learners. Although Varol (2015) investigated whether there was a pragmatic transfer from learners' L1 Turkish to their L2 English in responding to compliments, her study was limited to learners' responses to compliments on a written discourse completion test (DCT). Moreover, generally studies (Istifçi, 2017; Tüzün, 2003; Varol, 2015) focused on responses to compliments rather than compliments themselves. The occurrence of negative pragmatic transfer in L2 learners' speech acts may cause communication breakdowns in their L2. Their utterances can even be perceived as impolite when they are not parallel with the pragmatic norms of L2. For this reason, the present study aims to figure out whether Turkish EFL learners of high proficiency transfer their L1 Turkish pragmatic norms to their L2 English compliments and responses to compliments.

\subsection{Literature review}

It is plausible to trace the roots of compliments to Austin's Speech Act Theory (1962). According to Austin, compliments belong to the "behabitives" category of speech acts. This category is used to describe "the notion of reaction to other people's behavior and fortunes and of attitudes and expressions of attitudes to someone else's past conduct or imminent conduct" (Austin, 1962, p. 159). Research has shown that compliments have different functions (Herbert, 1989; Holmes, 1988). One of the most obvious functions of them is to enhance solidarity between the complimenter and the addressee (Holmes, 
1988). When a compliment is given, the complimenter expects a response to his/her compliment in return. Pomerant (1978), who was one of the first to study compliment responses, suggests that complimentees are generally confronted with a dilemma of either accepting the compliment or avoiding self-praise. Compliment responses tend to occur as second assessments that are constructed to agree or disagree with the prior compliments.

Complimenting is a complex behavior as it has many facets to consider. Based on Brown and Levinson's analysis of politeness (1987), Holmes suggests that compliments and responses to compliments can be perceived as face-threatening acts. That is, complimenting can threaten the addressee's negative face, and compliment responses can threaten the complimenter's positive face. Compliments can indicate " some desire of S (speaker) toward H (hearer) or H's goods giving H reason to think that he may have to take action to protect the object of S's desire, or give it to S" ( Brown \& Levinson, 1987, p. 66). In other words, the speaker may envy the addressee or would like to possess something that belongs to the addressee (Holmes, 1988). Similarly, accepting compliments can threaten the speaker's face as he or she may feel a need to downgrade the thing that the hearer complimented or may feel obligated to return the hearer's compliment (Brown \& Levinson, 1987). That's to say, this requires L2 learners to be careful in their use of compliments and responses to compliments in L2 to avoid such threats and to make better use of the functions of compliments in L2 appropriately. To date, there have been many studies that compare compliments and compliment responses across different languages (Billmyer, 1990; Cheng, 2011; Golato, 2002; Lorenzo-Dus, 2001; Saito \& Beecken, 1997; $\mathrm{Yu}, 2005)$. Han (1992) investigated how Korean females responded to compliments in English and Korean interactions. Fieldnotes and interviews were employed to collect the data. In her study, it was observed that Korean females responded to compliments differently in Korean and English. Korean females tended to accept compliments in English interactions and reject or deflect them in Korean interactions. In her study there was little evidence that indicated pragmatic transfer. Likewise, Golato (2002) did a research study by comparing German and American compliment responses. She used conversational analysis as the methodological framework. Golato (2002) found out that "while rejections and turns containing certain agreement and disagreement features are constructed similarly in German and American English, it is in agreement sequences that the two languages differ" (p. 547).

There have been several studies investigating compliment responses of Turkish EFL learners (İstifci, 2017; Varol, 2015). İstifçi (2017) compared Turkish and Chinese EFL learners' compliment responses using a DCT. Varol (2015), as mentioned earlier, carried out a study in order to investigate whether Turkish EFL students of pre-intermediate and advanced proficiency levels in English transfer pragmatic aspects from L1 Turkish to L2 English in their compliment response strategies. In her study, the data were collected from three groups as native speakers of both Turkish and English in addition to Turkish EFL students through a written DCT. The findings of Varol's study (2015) revealed that all the groups mostly preferred accepting and deflecting strategies. There were indications of both positive and negative transfer in the English compliment responses of Turkish EFL learners. While the signs of positive transfer were mostly observed in their preference for accepting and deflecting strategies, the traces of negative transfer were seen particularly in the use of returning strategy, pointing to the excessive use of L1-like expressions and the literal transfer of them. This study differs from her study methodologically as the current study uses role play for data collection. Apart from these, it is worth mentioning Dörtkulak's (2017) study in which she carried out a contrastive corpus-driven study and analyzed Turkish and American people's compliments and responses to compliments on Facebook. Her study pointed to cultural elements peculiar to Turkish culture in compliment responses of Turkish people. 
The literature on compliments in Turkish is rather scarce (Dörtkulak, 2017; Ruhi, 2006; Şakırgil \& Çubukçu, 2013; Varol, 2015), which is a hindrance to understanding L1 pragmatic norms and their effects on L2 learning in complimenting behavior. Within this respect, current study aims to examine both compliments and responses to compliments of Turkish EFL learners, using open role plays in both English and Turkish to collect data, distinguishing it from the previous studies on compliments in Turkish and many cross-cultural studies.

\subsection{Research questions}

Accordingly, the research questions which motivated this study and sub-questions of them are as follows:

1. Is there evidence of pragmatic transfer from L1 to L2 in Turkish EFL learners' compliment strategies?

1.1. What are the compliment strategies performed by Turkish EFL learners in Turkish?

1.2. What are the compliment strategies performed by Turkish EFL learners in English?

2. Is there evidence of pragmatic transfer from L1 to L2 in Turkish EFL learners' responses to compliment strategies?

2.1. What are the response to compliment strategies performed by Turkish EFL learners in Turkish?

2.2. What are the response to compliment strategies performed by Turkish EFL learners in English?

\section{Method}

\subsection{Participants}

Six Turkish EFL students participated in the study in 2017. They were senior undergraduate students studying in the ELT Program at a state university in Turkey. None of the participants studied or traveled abroad according to their self-reports. They had spent a mean length of 12 years of learning English by the time the data were collected. There were 1 male and five female participants in the study and their ages ranged between 20 and 22 years with an average of 20.83 years. The students had taken two linguistic courses in which they were familiar to pragmatics so far.

The choice of senior ELT students for this study was deliberate for two reasons. Firstly, they were chosen because they were assumed to be advanced level students in English. Sampling of a lowerproficiency group in English might inhibit the observance of possible pragmatic transfer due to their lack of proficiency in verbalizing their utterances. Secondly, it was more convenient for the researcher to work with this group. In other words, convenient sampling was adopted for the current study. Lastly, it should be noted that the participants volunteered for the study.

\subsection{Instrument(s)}

The data were collected through an open role play, an adapted version of the one prepared by Tran (2006). Role plays can be described as "simulations of social interaction" in which participants are assigned roles for given situations (Tran, 2006, p. 3). According to Kasper and Dahl (1991), the use of open role plays provides researchers with the opportunities to examine speech act utterances, by considering all their discourse features. In addition, Kasper and Dahl suggested that open role plays provide more naturalistic data when compared to other types of elicited data like discourse completion data. For these reasons, an open role play was used for this study. However, it is essential to acknowledge that there are some disadvantages of using role plays, too. One of them is that role plays are timeconsuming since researchers need to transcribe the role-play data (Kasper \& Dahl, 1991). 
The topics used for complimenting in the original role-play are achievement (performing a presentation), possession (a new car), appearance and clothing (Tran, 2006). The same role play was held both in Turkish and English for the current study. Therefore, the original role play was translated into Turkish by the researcher and the appropriateness of the translated version was checked by two experts (a professor in ELT program and a PhD student in ELT). A pilot study of role-play in its Turkish version was carried out with two senior ELT students. Since the second part of the role play (complimenting on appearance and clothing) did not seem to be efficient in eliciting natural data of complimenting within Turkish context, the researcher decided to specify the relevant cases of compliments ( hairstyle/ haircut under the category of appearance and dress/ suit for clothing) rather than using 'appearance' and 'clothing' in general terms.

\subsection{Data collection procedures}

The data were collected through an open role-play method, as was mentioned before. In an open role play, the initial situations are defined along with the role of each actor involved on a role card. Nevertheless, how the interaction will go on or how it will result is not specified (Kasper, 1999). In the present study, three pairs (6 university students) took part in the study. Participants firstly performed the role play in Turkish. The role play was carried out with each pair one by one. The students in each pair were divided into two as Student A and Student B, and they were provided with cards that included the descriptions of the situations and their roles (please see Appendix B). There were two scenarios, each including two compliment situations. Student B was asked to initiate the conversation in both scenarios. That is, Student B was expected to produce compliments, and Student A was expected to respond to compliments produced by Student B in each turn. It took each pair approximately 5 minutes to complete the role play. Finally, it is worth noting that the whole role-play process was audiotaped by the researcher. Please see appendices for the situations used for Student A and Student B in two languages.

The same role play process was carried out in English with the same students one week later. The same students were required to be the same type of students in the second role play, as well. In other words, if a student was given the role of Student A in the previous role-play, then he/ she was assigned the same role in the English role-play, too. In this way, we could obtain the data set of the same students either in compliments or responses to compliments both in Turkish and English.

\subsection{Data analysis}

Two different data sets were obtained in both Turkish and English through role plays for this study. The role play data were transcribed by the researcher and analyzed qualitatively for this study. Two different coding schemas were adopted as the study looked at two different speech acts. The first coding schema was developed to analyze the compliment strategies based the three different coding schemas used in the studies of Yuan (2002), Yu (2005) and Lin et al. (2012). The adapted Compliment strategy framework consisted of two macro levels as direct compliments and indirect compliments and their subcategories.

The second coding schema used for the study was adapted from Pomerantz (1978), Holmes (1988) and Cheng (2011) to analyze the compliment responses. The adapted framework consisted of three main categories as Accept compliments, Reject compliments, Deflect/ Evade compliments and their subcategories as can be seen in the following sections.

The data both in Turkish and English were coded to account for the similarities and differences in the use of strategies in each language by the participants, and to see whether there is any evidence of pragmatic transfer from Turkish to English in the compliment and response to compliment strategies of Turkish EFL students. The frequency and percentage calculations were held for each category and it is 
worth noting here that an utterance or utterance unit in one single speaker's turn was categorized as one strategy both for compliments and responses to compliments for the present study.

Due to the time constraints of available coders, only $25 \%$ of the compliment data in English and 24 $\%$ of the response to compliment data in English were coded by a second coder (PhD Student in ELT Program) for the reliability of the coding. The inter-coder reliability was calculated using Miles and Huberman (1994)'s reliability formula as given below:

Reliability $=$ number of agreements (same coding) $/$ total codes (agreement plus disagreements).(Miles \& Huberman, 1994).

Accordingly, the reliability between the coders was reported as 0.71 for the compliment strategies in English and similarly, the inter-coder reliability was calculated as 0.85 for responses to compliments in English. In addition, the opinion of a lecturer who has a $\mathrm{PhD}$ degree in Turkish Language and Literature was taken regarding the appropriateness of the examples that the researcher determined as having pragmatic transfer from the data.

\section{Results}

\subsection{Compliment strategies in Turkish and in English}

With respect to the $1^{\text {st }}$ research question and the sub-questions of the study, compliment strategies of Turkish EFL learners were investigated both in Turkish and in English through the use of role plays carried out in these two languages. Two macro levels were determined as direct and indirect compliment strategies, consisting of various sub-categories.

Table 1 shows the classification compliment strategies produced by Turkish EFL learners in the Turkish role play and Table 2 includes the categorization of the compliment strategies used by the same participants in English version of the role play.

Table 1. Categories of compliment strategies in Turkish

Compliment type Examples

I. Direct Compliments

1. Unbound explicit compliments

Bugün yaptığın sunum gayet güzeldi. Çok beğendim. (C1)

Ayrıca da yeni arabana bayıldım. (C2)

\section{Accompanied by explanations}

\section{Accompanied by wishes}

4. Accompanied by Congratulation

II. Indirect Compliments

1. Unbound assumption

2. Indicating notice
Ya kıyamam evet bugün sunumun vardı ama yani bence iyiydi ya aktivitelerini ben çok beğendim. Sence nasıldı? (C3).

Yok kanka çok güzel olmuş tam böyle yani sana çok yakışmış öğretmen gibi olmuşsun. Parti için bence kıyafetlerin çok güzel sunumdan çıktın ya kıyafetin düzgün yani gelebilirsin bence (C3).

Ayrıca yeni arabanı çok beğendim umarım kazasız belasız sürersin (C1)

Kıyafet konusunda da yine güzel bir seçim yapmışsın tebrik ederim $(\mathrm{C} 1)$

Sanırım iyi hazırlanmışsın $(\mathrm{C} 1)$

Elbiseni de yeni almışsın bunu hiç görmedim daha önce (C2)

Note: $\mathrm{C}$ refers to complimenter 
It is possible to see the categories of compliment strategies used by the participants in English and related examples in Table 2. As can be noticed, English compliment strategies of the Turkish EFL students consist of two main categories, which are direct compliments and indirect compliments as in Turkish.

Table 2. Categories of compliment strategies in English

Compliment Type $\quad$ Examples

I. Direct Compliments

1. Unbound explicit compliments

2. Accompanied by Explanations

3. Accompanied by Assumption

II. Indirect Compliments

1. Unbound Assumption

2. Unbound Wishing

3. Indicating Reference

\author{
You were great I think in the presentation $(\mathrm{C} 2)$ \\ You look so energetic and young (C2) \\ I loved your new car (C3). \\ That hair fits you so much. It looks adorable, I \\ think (C3).
}

I think your pictures and your presentation was perfect because you were so fluent $(\mathrm{C} 2)$

And I love the color of your car. I love blue so much (C2).

Yes, it looks different, but it is a nice difference (C3)

And I like your jacket also. I think it is really expensive one (C1).

And I think you very well prepared for the presentation $(\mathrm{C} 1)$

Yes, good luck with your car and I hope you wouldn't have any accidents (C1).

And also the teacher made good compliments about you (C3)

The compliment strategies coded in Turkish and some examples equated with them are given in Table 1. Similarly, Table 2 presents the compliment strategies and some examples from the English role-play data. An examination of the examples indicates many parallel structures in Turkish and English by the same complimenter. The same participants adhere to their preferences in Turkish in their use of compliment strategies in English. There is clear evidence of negative pragmatic transfer in some cases. For instance, $\mathrm{C} 1$ compliments on R1's new car by offering wishes from Turkish socio-pragmatic norms. In Turkish role- play, he says "Ayrıca yeni arabanı çok beğendim umarım kazasız belasız sürersin." Likewise, he transfers this to L2 and says "Yes, good luck with your car and I hope you wouldn't have any accidents", which does not seem to reflect L2 pragmatic norms. C3 says "That hair fits you so much. It looks adorable I think." when complimenting R3's new hair style. The first part of the utterance seems to include pragmatic transfer from L1 as C3 probably meant "yakışmak" (suit), which is not a frequent preference to use in $\mathrm{L} 2$. 
Table 3 shows the frequency and percentages of the compliments produced by Turkish EFL learners in their Turkish role play.

Table 3. Frequency and percentages of compliment strategies in Turkish

\begin{tabular}{lll}
\hline Categories & Frequency & Percentage \\
\hline Direct Compliments & & \\
$\quad$ Unbound explicit compliments & 7 & 41.18 \\
Accompanied by explanations & 5 & 29.41 \\
Accompanied by wishes & 1 & 5.88 \\
Accompanied by Congratulation & 1 & 5.88 \\
Total & 14 & 82.35 \\
& & \\
Indirect Compliments & 2 & 11.76 \\
$\quad$ Unbound Assumption & 1 & 5.88 \\
Indicating notice & 3 & 17.65 \\
$\quad$ Total & 17 & \\
Total & & \\
\hline
\end{tabular}

It is possible to look at the frequency and percentages of the compliments produced by Turkish EFL learners in their English role play in Table 4.

Table 4. Frequency and percentages of compliment strategies in English

\begin{tabular}{lll}
\hline Categories & Frequency & Percentage \\
\hline Direct Compliments & & \\
$\quad$ Unbound explicit compliments & 18 & 64.28 \\
Accompanied by explanations & 6 & 21.43 \\
Accompanied by assumptions & 1 & 3.57 \\
$\quad$ Total & 25 & 89.28 \\
Indirect Compliments & 1 & 3.57 \\
$\quad$ Unbound assumption & 1 & 3.57 \\
$\quad$ Unbound wishing & 1 & 3.57 \\
$\quad$ Indicating reference & 3 & 10.71 \\
Total & & \\
Total & 28 & \\
\hline
\end{tabular}

As can be seen in Table 3 and Table 4, participants preferred direct complimenting in both Turkish (\% 82.35) and English (\% 89.28). It is apparent that they used it more in English with a slight difference of percentage. Unbound explicit compliments were the most preferred strategies in both languages, $(\%$ 41. 18 for Turkish; $\% 64.28$ for English) followed by Accompanied by explanation in the second rank for both data. Indirect compliments comprised the percentage of 11.26 for Turkish compliments while they occurred with a percentage of 10.71 in English as can be seen in the tables. In addition, as shown in the given tables, the learners employed different types in English and Turkish. Three of them were the same compliment strategy types preferred in both languages as can be seen in the following tables. With respect to the first research question that addresses the pragmatic transfer issue in the Turkish EFL learners' compliment strategies, it is only possible to suggest that there is a sign of pragmatic transfer from L1 Turkish to L2 English in Accompanied by Explanations compliment strategy at the level of 
direct compliments when we look at the frequency and percentage calculations of compliment strategies in the tables.

\subsection{Response to compliment strategies in Turkish and English}

Table 5 includes the classification the response to compliment strategies that emerged in Turkish role play while Table 6 presents the response to compliment strategies in English.

Table 5. Compliment responses in Turkish

\begin{tabular}{ll}
\hline Types of Compliment Responses & Examples \\
\hline I. Accept & Çok teşekkür ederim (R1) \\
$\begin{array}{l}\text { 1. Appreciation } \\
\text { 2. Agreement }\end{array}$ & Evet bu sunum için ben çok çalıştım. (R1) \\
II. Reject & Ben çok emin olamadım ya. Ehh işte fena \\
1. Disagreement & değildi. (R3) \\
& Dilbilim ya birazcık emin olamadım. (R3) \\
III. Deflect/ Evade & Ya gerçekten iyi miydi? (R2) \\
1. Confirmation Question & Yeni kestirdim güzel olmuş mu? (R2) \\
& Evet biraz değişiklik istedim hem hayatımda hem \\
2. Explanation & saçımda.(R1) \\
& Teşekkür ederim bu yılın modası böyle. (R1). \\
& Ya al ama ya ben seni gezdiririm ama (R3). \\
3. Suggestion/ Offering & Teşekkür ederim babam sağolsun (R2)
\end{tabular}

Note: R stands for respondent.

Table 6 shows the compliment responses of Turkish EFL learners given to their pairs' compliments in English role play. Three main categories emerged in relation to the compliment responses of the participants in their L2 English, which was the case in their L1. However, it is worth noting that the subcategories of compliment responses of the participants varied to some degree in their L1 and L2, which is clear in both tables.

Table 6. Compliment responses in English

\section{Accept}

\section{Appreciation}

2. Agreement

\section{Return Compliment}

Oh thank you. (R1)

Oh Thanks, you made me feel better now. (R2)

Yes, it looks so gorgeous (R1)

Blue is the best (R3)

Oh thank you it is very kind of you to say things like that. (R1). 
Thank you because it is the eyes that looking beautiful to me. (R2)

II. Reject

1. Disagreement

II. Deflect/ Evade

1. Confirmation Question

2. Explanation
I am not sure. I feel a bit sad. (R3)

I am not sure... When I am looking mirror, I feel something different (R3)

Really? (R2)

Really? Did you like the color? (R2)

Oh thank you. Did you realize that I had my hair cut?

(R2)

Do you think so? (R3)

Thank you, they are my favorite colors. (R1)

Yes, I really dreamed about the jacket and I finally bought it (R1)

And we can travel wherever you want. (R3).

I wish you have better than my car. (R2)

Three main categories were determined as ACCEPT, REJECT and DEFLECT/ EVADE in both data consisting of sub-categorizations of responses to compliments. Examples from the data can be seen regarding response to compliment strategies in Turkish in Table 5 and examples from the English role play data regarding response to compliments are given in Table 6. Parallel structures can be observed in these data sets, as well. For instance, the two instances of disagreements belong to R3 both in Turkish response to compliments and the English ones. There are some clear signs of negative pragmatic transfer in some of the examples. For instance, when C2 compliments on R2's appearance, she replies as "Thank you because it is the eyes that looking beautiful to me". She probably meant to say "o senin bakışının güzelliği”", a common expression used by women in response to compliments on their appearance in Turkey. That's to say, R2 used Turkish cultural features in her utterances when returning compliments to the complimenter in English, which might not be acceptable or understandable in the target pragmatic norms.

Table 8 shows the frequency and percentages of responses given by the participants to the compliments of their interlocutors in Turkish.

Table 8. Frequency and percentages of compliment response strategies in Turkish

\begin{tabular}{llll}
\hline Categories & Frequency & Percentage \\
\hline Accept & & 2 & 11.76 \\
& Appreciation & 2 & 11.76 \\
& Agreement & 2 & 23.53 \\
& Total & 4 & 11.76 \\
Reject & & & 11.76
\end{tabular}

Deflect/ Evade 
Confirmation Questions 4

Explanation 5

You can see the frequency and percentages of responses given by the participants to the compliments of their interlocutors in their L2 English in Table 9.

Table 9. Frequency and percentages of compliment response strategies in English

\begin{tabular}{|c|c|c|}
\hline Categories & Frequency & Percentage \\
\hline \multicolumn{3}{|l|}{ Accept } \\
\hline Appreciation & 5 & 19.23 \\
\hline Agreement & 4 & 15.38 \\
\hline Returning compliments & 2 & 7.69 \\
\hline Total & 11 & 42.31 \\
\hline \multicolumn{3}{|l|}{ Reject } \\
\hline Disagreement & 2 & 7.69 \\
\hline Total & 2 & 7.69 \\
\hline \multicolumn{3}{|l|}{ Deflect/ Evade } \\
\hline Confirmation Questions & 7 & 26.92 \\
\hline Explanation & 4 & 15.38 \\
\hline Suggestion/Offering & 1 & 3.85 \\
\hline Wish & 1 & 3.85 \\
\hline Total & 13 & 50.00 \\
\hline Total & 26 & \\
\hline
\end{tabular}

Looking at the frequency and percentages of compliment response strategies, it may be easier to trace the signs of pragmatic transfer in Turkish EFL learners' compliment response strategies. Deflect-Evade strategies were the most frequently used in both Turkish with a percentage of 64.71 and in English with a percentage of 50.00. The second most preferred response to compliment strategy was Accept for both data. Yet, it emerged with a greater percentage in English (42.31) than in Turkish data (\% 23.53). There were only two instances of Reject category in both languages, as can be seen in Table 8 and Table 9 . Moreover, looking at the frequency and percentage calculations of the compliment strategies used in Turkish and English, it is plausible to claim that there is some evidence of pragmatic transfer from L1 Turkish to L2 English in Deflect/ Evade response to compliment strategy especially in the sub-category of explanation in response to the second research question of this study.

\section{Discussion}

The findings of the present study showed that direct compliments were the most preferred compliment strategy by Turkish EFL learners in Turkish and English and they made use of very few cases of indirect compliments in both languages. However, the findings indicated that the indirect compliment strategies used by Turkish EFL in Turkish learners outnumbered those produced in English by the same speakers. The presence of both direct and indirect compliment strategies in L1 Turkish and L2 English for Turkish 
EFL learners is in line with the findings of Yu (2005)'s ethnographic study, which revealed that the use of both direct and indirect compliments was observed in Chinese and English, thereby pointing to "the cross-linguistic validity" of these two strategies (Yu, 2005, p. 113). Likewise, these findings are in line with Lin et al. (2012)'s study, which found that Taiwanese Chinese and Mainland Chinese students preferred explicitness, directness in a sense for our study, in their use of complimenting strategies.

Similarly, in Yu (2005)'s study, indirect compliments strategies were used more by Chinese than American English speakers. The use of more directness in L2 English with even with a slight difference than in Turkish as desired by American English speakers implies that the participants of the present study might have acquired the target L2 pragmatic norms. However, it is worth noting here that none of the participants in this study have been abroad according to their self-reports. Therefore, this might be attributed to L2 classroom instruction and pragmatic courses that they have taken at university or it may be related to the out-of-class activities these students are involved in. With the introduction of technology into human life and with the increasing globalization, it seems reasonable to claim people are more exposed to English than before. English as being the lingua franca is seen prevalently in many different parts of people's lives. That is to say, it is possible to state that L2 learners are more and more in contact with both native speakers of English and other non-native speakers of English. Similarly, L2 learners like other people have the opportunity to watch many movies or tv series or shows in English via internet, which might have a considerable amount of impact on their pragmatic competence, including how to compliment somebody in English and how to respond to compliments in English.

The findings of the present study also suggest that there is a sign of negative pragmatic transfer from L1 Turkish to L2 English in Accompanied by Explanations compliment strategy at the level of direct compliments. They use explicit compliments followed with explanations very frequently in Turkish and the same tendency is observed in English. The participants also used features that reflect Turkish culture in their English compliments. That's to say, there were clear examples of negative pragmatic transfer from Turkish to English in Turkish EFL learners' compliments in English. As they use the aforementioned strategy more frequently in Turkish than in English, it can be assumed that they have transferred this pragmatic norm from L1 Turkish to L2 English. The use of explanations in explicit compliments might be related to the fact that their interlocutors often want to be confirmed about the compliments that they take, which is clear in their confirmation questions. In other words, the complimenters might have attempted to (re)assure their interlocutors about their positive aspects.

With respect to the second research question of the present study, which is about compliment response strategies of Turkish EFL learners in their L1Turkish and L2 English, three main categories were determined as accepting compliments, rejecting compliments and deflecting/evading compliments in both data. Deflect-Evade strategies were the most common strategies in the two data sets with a higher frequency in L1, unlike what is indicated in Varol (2015)'s study. She found that accepting compliments was the most preferred strategy adopted by Turkish EFL learners and native speakers of English, as well. This discrepancy can be explained by the use of different research instruments for the two studies. Varol (2015) collected the data through a DCT, yet I preferred to use open role plays to elicit more natural data. Moreover, the greatest use of Deflect and Evade strategies by Turkish EFL learners might be related to their putative low self-evaluations of the credibility of the compliments they received. This can also be explained by the view that compliments are face threatening acts both for both interlocutors (Holmes, 1988) and the receiver might have attempted to show modesty in a sense to avoid the threats involved.

In the present study, the second most preferred compliment response strategy was Accept for both in English and in Turkish by the participants. It emerged with a greater frequency in English than in Turkish data, but not at a satisfactory level because generally the studies indicate that American English speakers show a tendency to accept compliments in most cases (Pomerantz, 1978; Saito \& Beecken, 1997). In this study, accepting compliments was not EFL learners' first choice in English. Turkish EFL learners 
preferred to use Deflect/Evade strategies more than the other compliment response strategies both in English and Turkish. Looking at the quantitative analysis of the compliment responses, it can be proposed that Turkish EFL learners have transferred Deflect/Evade strategy especially in the subcategory of Explanation from their L1 to their interlanguage. This claim can be supported by the results of Saito and Beecken's study (1997). According to their study, American learners of Japanese transferred nonuse of "avoidance" strategies from their L1 English into their L2 Japanese. In other words, using Deflect/ Evade strategies is not deemed as desirable or preferable in English, the model behavior would be to accept the compliments (Pomerantz, 1978). In the present study, Accept strategy was the second most frequent compliment response strategy and it occurred with a greater percentage in L2 English than in Turkish data, yet not at a satisfactory level apparently.

A detailed analysis of the qualitative data reveals a sign of negative transfer in the compliment responses produced by Turkish EFL learners in their L2 English as they sometimes used Turkish cultural features in their responses to English compliments, especially when returning compliments to their interlocutors, which does not seem to be parallel with the L2 pragmatic norms. Dörtkulak (2017) found that Turkish people used cultural elements peculiar to Turkish culture in their compliment responses in Turkish. Apparently, Turkish EFL learners transfer these elements to their L2 English without considering whether they are appropriate or understandable in L2 or not.

\section{Conclusion}

The present study aimed to look at the compliment strategies and compliment response strategies used by Turkish EFL learners in L1 Turkish and L2 English and, to see whether there is evidence of pragmatic transfer (negative) from Turkish to their interlanguage in those strategies. For this purpose, a role play in Turkish and English was carried out for the same participants one week apart as the data collection techniques. This study yielded the following results:

Firstly, Turkish EFL students preferred to use direct compliments more both in Turkish and L2 English with a higher percentage in English as often desired in American English. Indirect strategies were rarely used in both data. The participants made use of a wide range of sub-categories in their compliment strategies, some of which change according to the language they use. Yet, there are many observable parallel structures between the Turkish compliment strategies and L2 English compliment strategies on an individualistic basis. There are even some cases of literal transfer of some idiomatic expressions, thus indicating the $\mathrm{L} 1$ as the reference point at least to some extent.

Secondly, the study suggested that there is sign of negative pragmatic transfer from L1 Turkish to L2 English in Accompanied by Explanations compliment strategy at the level of direct compliments. That is to say, they tend to overuse explicit compliments followed by explanations in their L2 as it is the tendency in their L1. Thirdly, three main categories were determined as accepting compliments, rejecting compliments and deflecting/evading compliments in both data regarding the compliment response strategies of Turkish EFL learners in their L1Turkish and L2 English. Deflect-Evade strategies were the most frequently used strategies in the two data sets with a higher frequency in L1. This does not reflect the common pragmatic norm in American English, in which accepting compliments is a greater tendency. Therefore, the study proposes that Turkish EFL learners have transferred the use of Deflect/ Evade strategy especially in the sub-category of Explanation from their L1 to their interlanguage, which points to traces of negative pragmatic transfer. Then, the second most preferred response to compliment strategy was Accept for both data. It emerged with a greater frequency in English than in Turkish data, yet not at a satisfactory level. In other words, they are more inclined to accept the compliments in English than in Turkish, but it is not their favorite one unlike the tendency in the target community. There were also some instances in which Turkish EFL learners transferred 
Turkish cultural features to their English utterances when returning compliments in English. Lastly, Turkish EFL learners tended to reject compliments only in two cases for this study.

This study has contributed to our understanding of the compliments and response to compliment strategies used by Turkish EFL learners both in Turkish and English. It has also enabled to trace the signs of negative pragmatic transfer occurring from Turkish to L2 English in their complimenting speech act.

\subsection{Implications and suggestions}

The findings of the present study have some educational implications for L2 learning and teaching. The analysis of the data revealed that there was a sign of negative pragmatic transfer of the compliment strategy Accompanied by Explanation at the level of direct complimenting from L1 Turkish to L2 English. Secondly, there are signs of pragmatic transfer in the use of Deflect/ Evade response to compliment strategy, especially at the Explanation sub-category from L1 to L2. In addition, Turkish EFL learners transferred (negative transfer) Turkish idiomatic expressions to their English while returning compliments in English in some cases. These may be related to lack of enough exposure to L2 or lack of instruction on the relevant speech acts in the classroom. In addition, although the Turkish EFL learners are more inclined to accept compliments in English than in Turkish, it is the second most preferred compliment response strategy unlike the greater tendency for American English speakers, referred in the literature. L2 learners should be able to use compliment strategies appropriately in L2 and respond to them in line with the target socio-pragmatic norms to communicate effectively and avoid misunderstandings or pragmatic failure. Therefore, L2 teachers should provide the students with the information regarding the differences between the L1 and L2 pragmatic norms and design activities that may reflect the target pragmatic norms. The teachers can also benefit from different settings or scenarios like the ones used in this study. This study used the role play as a research instrument to collect data, but teachers can make use of such role plays or some drama activities as classroom activities while teaching speech acts like compliments to students. L2 Learners in EFL context should be encouraged to make use of technology with the purpose of increasing their familiarity with the target L2 pragmatic norms in mind. For instance, L2 learners can be encouraged to watch movies and series in English so that they can understand the pragmatic norms of L2 culture.

The study has focused on two speech acts, compliments and responses to compliments, produced by a limited number of participants. Further research might use a larger sample and include the native speakers of English. Future research could also expand the scope of the study by involving different status- interlocutors. In addition, gender might be a very important variable in understanding the nature of compliments and responses to compliments. Therefore, further research could examine gender in the given speech acts.

\section{Ethics Committee Approval}

The author(s) confirm(s) that the study does not need ethics committee approval according to the research integrity rules in their country (Date of Confirmation: August 18, 2020).

\section{References}

Austin, J. L. (1962). How to do things with words. Oxford: Clarendon

Billmyer, K. (1990). "I really like your lifestyle": ESL learners learning how to compliment. Working Papers in Educational Linguistics, 6(2), 31-48. 
Brown, P., \& Levinson, S. C. (1987). Politeness: Some universals in language usage. New York: Cambridge University.

Cheng, D., (2011). New insights on compliment responses: A comparison between native English speakers and Chinese L2 speakers. Journal of Pragmatics, 43(8), 2204-2214. Doi: https://doi.org/10.1016/j.pragma.2011.02.003

Dörtkulak, F. (2017). Compliments and compliment responses in Turkish and American English: a contrastive pragmatics study of a facebook corpus (Unpublished PhD thesis). Orta Doğu Teknik Üniversitesi, Sosyal Bilimler Enstitüsü, İngiliz Dili Eğitimi Anabilim Dalı, Ankara.

Gass, S., Behney, J., \& Plonsky, L. (2013). Second language acquisition: An introductory course. New York: Routledge.

Golato, A. (2002). German compliment responses. Journal of Pragmatics, 34(5), 547-571.

Han, C. (1992.) A comparative study of compliment responses: Korean females in Korean interactions and in English interactions. Working Papers in Educational Linguistics, 8(2), 1731.

Herbert, R. (1989). The ethnography of English compliments and compliment responses: A contrastive sketch. In W. Oleksy (Eds.), Contrastive pragmatics (pp. 3-35), Amsterdam: John Benjamins.

Holmes, J. (1988). Paying compliments: a sex-preferential politeness strategy. Journal of Pragmatics 12(4), 445-465.

Istifci, I. (2017). Comparison of Chinese and Turkish EFL learners on the use of compliment responses. Journal of Language and Linguistic Studies, 13(2), 14-29.

Karagöz, T., \& Isisag, K. U. (2019). An investigation into the request realization patterns of Turkish ELT students. Novitas-ROYAL (Research on Youth and Language), 13(1), 84-102.

Kasper, G. (1992). Pragmatic transfer. Second Language Research, 8(3). 203-231.

Kasper, G. (1999). Data collection in pragmatics research. University of Hawai'i Working Papers in English as a Second Language, 18(1). 71-107.

Kasper, G., \& Dahl, M. (1991). Research methods in interlanguage pragmatics. Studies in Second Language Acquisition, 13(2), 215-247. Doi: https://doi.org/10.1017/S0272263100009955

Lorenzo-Dus, N. (2001). Compliment responses among British and Spanish university students: A contrastive study. Journal of Pragmatics, 33(1), 107-127. Doi: https://doi.org/10.1016/S0378 2166(99)00127-7

Lin, C.Y., Woodfield, H., \& Ren, W. (2012). Compliments in Taiwan and Mainland Chinese: The influence of region and compliment topic. Journal of Pragmatics, 44(11), 1486-1502. Doi: https://doi.org/10.1016/j.pragma.2012.06.012

Miles, M. B. \& Huberman A.M. (1994). Qualitative data analysis: An expanded sourcebook.. Calif: Sage Publications.

Pomerantz, A. (1978). Compliment responses: Notes on the co-operation of multiple constraints. In J. Schenkein (Eds.), Studies in the organization of conversational interaction (pp. 79-112). New York: Academic Press. 
Ruhi, Ş. (2006). Politeness in compliment responses: A perspective from naturally occurring exchanges in Turkish. Pragmatics, 16(1). 43-101. Doi: https://doi.org/10.1075/prag.16.1.03ruh

Saito, H., \& Beecken, M. (1997). An approach to instruction of pragmatic aspects: implications of pragmatic transfer by American learners of Japanese. Modern Language Journal, 81(3), 363-377. Doi: https://doi.org/10.1111/j.1540-4781.1997.tb05497.x

Şakırgil, C., \& Çubukçu, H. (2013). Formulas and topics in Turkish and English compliments. Procedia - Social and Behavioral Sciences, 70, 1126-1135. Doi: https://doi.org/10.1016/j.sbspro.2013.01.168

Tran, G. Q. (2006). The naturalized role-play: An innovative methodology in cross-cultural and interlanguage pragmatics research. Reflections on English Language Teaching, 5(2), 1-24.

Thomas, J. (1983). Cross-cultural pragmatic failure. Applied Linguistics, 4(2), 91-112.

Tüzün, D. (2003). Compliment responses in English and Turkish with implications for language learning (Unpublished Master's thesis). Uludağ Üniversitesi, Sosyal Bilimler Ensititüsü, İngiliz Dili Eğitimi Anabilim Dalı, Bursa.

Varol, B. (2015). Transfer effects in compliment responses of EFL learners. International Journalof Arts \& Science, 08(06), 513-522.

Wierzbicka, A. (1985). Different cultures, different languages, different speech acts: Polish vs. English. Journal of pragmatics, 9(2-3), 145-178. Doi: https://doi.org/10.1016/0378 2166(85)90023-2

Yu, M. (2005). Sociolinguistic competence in the complimenting act of native Chinese and American English speakers: A mirror of cultural value. Language and Speech, 48(1), 91-119. Doi: https://doi.org/10.1177/00238309050480010501

Yuan, Y. (2002). Compliments and compliment responses in Kunming Chinese. Pragmatics, 12(2), 183-226. Doi: https://doi.org/10.1075/prag.12.2.04yua

\section{Appendix A. Open role play in English}

\section{Situation 1}

\section{Student A:}

Today you have made a presentation in your linguistics class. After class, while you are walking in the parking lot towards your new car, which was your father's present, one of your classmates approaches you. You two have a conversation.

\section{Situation 1}

\section{Student B:}

Today one of your classmates has made a presentation in your linguistics class. After class, you happen to see your classmate in the parking lot. Please have a natural conversation with him/her in which you will compliment him/her on his/her presentation and his/her new car. 


\section{Situation 2}

\section{Student A:}

You dressed up for a party at that classmate's house. Today you also had your hair cut. Now you are at your classmate's doorstep. You two have a conversation.

\section{Situation 2}

\section{Student B:}

You invited this classmate to a dinner party of classmates at your house. Now you are greeting him/her at the door. Please have a natural conversation with him/her in which you will compliment him/her on his/her appearance (new hair style/ haircut) and clothing (dress/ jacket).

\section{Appendix B. Open role play in Turkish}

\section{Senaryo 1:}

\section{A öğrencisi:}

Bugün dilbilim dersinizde sunumunuz vardı. Ders çıkışı park yerinde babanızın size yeni aldığı arabanıza doğru yürürken sınıf arkadaşlarınızdan birisiyle karşılaşıyorsunuz. İkinizin arasında bir konuşma geçecek (geçsin).

\section{Senaryo 1:}

\section{B öğrencisi:}

Bugün sınıf arkadaşlarınızdan birisi dilbilim dersinizde sunum yaptı. Ders çıkışı park yerinde onunla karşılaşıyorsunuz. Lütfen doğal bir konuşma başlatın. Yaptığı sunuma ve yeni arabasına iltifat edin.

\section{Senaryo 2:}

\section{A öğrencisi:}

Sınıf arkadaşınızın evinde gerçekleşecek olan parti için giyinip hazırlandınız. Ayrıca gün içerisinde saçınızı kestirdiniz. Şu an onun evinin kapsısındasınız. İkinizin arasında bir konuşma geçecek(geçsin).

\section{Senaryo 2:}

\section{B öğrencisi:}

$\mathrm{Bu}$ arkadaşınızı arkadaşlarınız için düzenlediğiniz akşamki partinize davet ettiniz. Şu an onu kapıda karş1lıyorsunuz. Lütfen ona görünüşü (saç stili/ saç kesimi) ve kıyafeti (elbise/ ceket) ile ilgili iltifatta bulunacağınız doğal bir konuşma başlatın. 


\section{İngilizce'yi yabancı dil olarak öğrenen Türk öğrencilerin iltifat etme ve iltifatlara karşılık verme biçimlerinde Türkçe'den İngilizce'ye edimbilimsel aktarım}

\section{$\ddot{O} \mathbf{z}$}

Bu araştırma, İngilizce'yi yabancı dil olarak öğrenen Türk öğrencilerin iltifat etme ve iltifatlara karşılık verme biçimlerinde Türkçe'lerinden İngilizce'lerine edimbilimsel aktarım olup olmadığını incelemektedir. Türkiye'de bir devlet üniversitesinde yürütülen çalışmaya altı tane İngiliz Dili Eğitimi Bölümü öğrencisi katılmıştır. Tran(2006)'dan uyarlanan açı rol oyun tekniği, katılımcıların İngilizce ve Türkçe'de iltifat ve iltifata karşılık verme stratejilerini toplamak amacıyla kullanılmıştır. Veri analizi, iki farklı kodlama şemasına göre gerçekleştirilmiştir. Katılımcıların iltifat stratejileri doğrudan iltifatlar ve dolaylı iltifatlar olmak üzerek iki makro seviyeden oluşmaktadır. Katılımcıların kendilerine yapılan iltifatlara nasıl karşılık verdiklerini analiz etmek için kullanılan şemaya göre ise iltifatları kabul etme, iltifatları reddetme ve iltifatları farkl yöne saptırma gibi üç temel kategori oluşturulmuştur. Araştırmanın sonuçları, katılımcıların ana dili olan Türkçe'den yabancı dili olan İngilizce'ye edimbilimsel aktarım izlerine işaret etmektedir. Bu aktarımlar, iltifat için doğrudan iltifatların alt kategorisinde yer alan Açıklamalı Ilttifat ve iltifatlarına verilen karşılıklar için iltifatları farklı yöne saptırma kategorisinin bir alt kategorisi olan Açıklama kategorisinde gözlemlenmektedir.

Anahtar Kelimeler: söz edimi; iltifat stratejisi; iltifata karşılık; edimbilimsel aktarım

\section{AUTHOR BIODATA}

Tuba Karagöz Dilek is currently doing her PhD at Gazi University. She studied English Linguistics at Hacettepe University and did her Master's degree at Gazi University. Her research interests include emotional intelligence, speech acts, and metaphors. 